Arab Univ. J. Agric. Sci., Ain Shams Univ., Cairo, 14(2), 813-821, 2006

\title{
ACTIVITY OF PEACH TWIG BORER Anarsia lineatella Zeller AND ITS ASSOCIATED BIO AGENTS ON PEACH TREES \\ [52]
}

\author{
Salwa S.M. Abdel-Samad ${ }^{1}$
}

\begin{abstract}
The seasonal activity of the peach twig borer, Anarsia lineatella Zeller was investigated during 2004 and 2005 seasons. The data revealed that the infested twigs empty from larvae $(15 \%)$ were higher than that with larvae $(1.25 \%)$ in February. The situation was reverse in April which recorded 8\% and $14.75 \%$ for both, respectively. In fruits, infestation began to appear in the third week of March which recorded $2 \%$ whereas the maximum rate was recorded in May $(16.75 \%)$. Three species of hymenopterous parasitoids were found; Apanteles ruficrus Haliday (Fam. Braconidae), Diplazon laetatorus Fab. (Fam. Ichneumonidae) and Microgaster tiro Reinhard (Fam. Braconidae). These parasitoids reached its maximum during April $(13.5 \%)$ that seems to be more active. Their numbers were positively correlated with the rate of infestation $(\mathrm{r}=+0.799)$. In spite of presence of four predatory species (Coccinella undecimpunctata L., Rodalia cardinalis Mulsant, and Scymnus syriacus Marseul (Coleoptera: Coccinellidae) and Syrphus sp. (Diptera: Syrphidae)), it seems to be less active. Their numbers recorded very slight positive correlation with the rate of infestation $(\mathrm{r}=+0.423)$
\end{abstract}

Keywords: Peach, Anarsia lineatella, Parasitoid, Predators, Biological control

\section{INTRODUCTION}

Peach fruits are considered one of the most popular fruits in Egypt. Peach orchards were attacked by several pests, but the most important pest was the peach twig borer, Anarsia lineatella Zeller (Lepidoptera: Gelechiidae) which cause damage to the newly formed twigs and fruits. The larvae bore into newly formed twigs and fruits causing partial or complete destruction. Many authors studied different subjects belong to this pest, most of them used pheromone traps for monitoring the flight activity (Molnar, 1991; Kehat et al 1994; Zalom et al 1992 and Kocourek et al 1996), mating disruption (confusion) (Molinari and Cravedi, 1991 and Pari et al 1990), determination the percentages of infestation (Hrdy et al 1994; Weakley et al 1990 and Hathaway et al 1985) and the effectiveness of the pheromone traps (Yonugman and Barnes, 1985 and Barnett and Hendricks, 1992).

1- Biological Control Department, Agric. Res. Center, Giza, Egypt

(Received April 16, 2006)

(Accepted June 21, 2006) 
According to biology, ecology and behaviour of the pest (Ivanova et al 1995). The biological control, especially parasites plays an important role for controlling such pest (Dimova, 1987 and Cravedi et al 1995).

The present study aimed to throw more light on the infestation of peach twig borer A. lineatella on peach trees and the role of associated predators and parasites for controlling such pest.

\section{MATERIAL AND METHODS}

The present investigation was carried out in a peach orchard of two feddans, located at Kotor District, Gharbia Governorate. Studies were conducted during two successive seasons, 2004 and 2005. Twenty trees (about 10 years old) were randomly chosen for sampling and five random twigs / tree (represented the four main directions and the central core) was collected periodically, started from the second week of February and ended in the last week of June in both seasons. One hundred fruits were also collected whenever it were available. Samples of either twigs or fruits were kept in paper bags and transferred to the laboratory for carefully examination to estimate the rate of infestation in twigs (either with or without larvae) and in fruits.

The infested twigs and fruits by larvae were confined in glass jars until emergence of adult parasitoids to estimate the rate of parasitism and identifying the emerged parasitoid species. The predators were directly counted and identified on twigs in the field.

\section{RESULTS}

The rate of infestation by peach twig borer Anarsia lineatella Zell which found in peach orchard during the two successive seasons of 2004, 2005 were listed in Table (1) and Fig. (1). The percentages of infestation in twigs were much higher for about 12 times in February in twigs empty from larvae than that with larvae. These averages are 15 and $1.25 \%$ for both, respectively. In May, the empty infested twigs decreased until reached its minimum $(5.5 \%)$, then increased again till reached $7.16 \%$ in June. On the other hand the infested twigs with larvae began to increase to reach its maximum (14.75\%) in April then decreased towards the end of season, which recorded $1.3 \%$ in June. The average percentage of infested twigs (with or without larvae) showed somewhat higher rate of infestation in February $(6.25 \%)$ and reached its maximum peak in April $(22.75 \%)$ then decreased gradually till $8.5 \%$ in June.

The infested fruits began to appear in the third week of March (2\%), and increased, gradually, till recorded the maximum rate $(16.75 \%)$ in May then decreased till reached 5.5\% in June.

The previous results showed that the twigs infestation with larvae which resume their activity appearance of the overwintered larvae where start boring in the shoots.

The larvae of peach twig borer in winter were hibernated in tunnels in the distal part of twigs (Saafan et al 1994 and Ivanova et al 1995), so the empty infested twigs in early season may be due to the migration of larvae either before or after hibernation searching for new vegetative parts and/or due to the effect of biological agents or other factors. When weather conditions became favourable, the overwintered larvae appear and resume their activity which starts boring 
in the shoots and twigs. Where the num-

bers

Arab Univ. J. Agric. Sci., 14(2), 2006 
Table 2. Occurrence of natural enemies (\% of parasitism and No. of predators) on peach twig borer, Anarsia lineatella during two successive seasons of 2004 and 2005

\begin{tabular}{|c|c|c|c|c|c|c|c|}
\hline \multirow{2}{*}{\multicolumn{2}{|c|}{$\begin{array}{c}\text { Inspection dates } \\
2004(05)\end{array}$}} & \multicolumn{3}{|c|}{$\%$ of parasitism } & \multicolumn{3}{|c|}{ No. of predators } \\
\hline & & 2004 & 2005 & Average & 2004 & 2005 & Average \\
\hline \multirow[t]{2}{*}{ Feb. } & $11(9)$ & 0 & 0 & 0 & 4 & 5 & 4.5 \\
\hline & $25(23)$ & 3 & 1 & 2 & 6 & 8 & 7 \\
\hline \multicolumn{2}{|c|}{ mean } & 1.5 & 0.5 & 1 & 5 & 6.5 & 5.75 \\
\hline \multicolumn{2}{|c|}{ March 10 (9) } & 9 & 6 & 7.5 & 10 & 9 & 9.5 \\
\hline & $24(23)$ & 16 & 10 & 13 & 11 & 13 & 12 \\
\hline \multicolumn{2}{|c|}{ mean } & 12.5 & 8 & 10.25 & 11 & 11 & 10.75 \\
\hline \multirow[t]{2}{*}{ April } & $7(6)$ & 17 & 13 & 15 & 13 & 16 & 14.5 \\
\hline & $21(20)$ & 13 & 11 & 12 & 21 & 29 & 25 \\
\hline \multicolumn{2}{|l|}{ mean } & 15 & 12 & 13.5 & 17 & 22.5 & 19.75 \\
\hline \multirow[t]{2}{*}{ May } & $5(4)$ & 10 & 9 & 9.5 & 26 & 31 & 28.5 \\
\hline & $19(18)$ & 9 & 7 & 8 & 24 & 23 & 23.5 \\
\hline \multicolumn{2}{|l|}{ mean } & 9.5 & 8 & 8.25 & 25 & 27 & 26 \\
\hline \multirow[t]{3}{*}{ Jun } & $2(1)$ & 8 & 9 & 8.5 & 20 & 22 & 21 \\
\hline & $16(15)$ & 4 & 6 & 5 & 17 & 22 & 19 \\
\hline & 30 (29) & 1 & 3 & 2 & 21 & 19 & 20 \\
\hline \multicolumn{2}{|c|}{ mean } & 6.5 & 9 & 5.16 & 19.3 & 21 & 20 \\
\hline \multirow{2}{*}{\multicolumn{2}{|c|}{$\begin{array}{c}\text { General mean } \\
\pm \text { s.e. }\end{array}$}} & 8.2 & 6.8 & 7.5 & 15.7 & 17.9 & 16.8 \\
\hline & & \pm 1.7 & \pm 1.2 & \pm 1.5 & \pm 2.2 & \pm 2.6 & \pm 2.4 \\
\hline
\end{tabular}

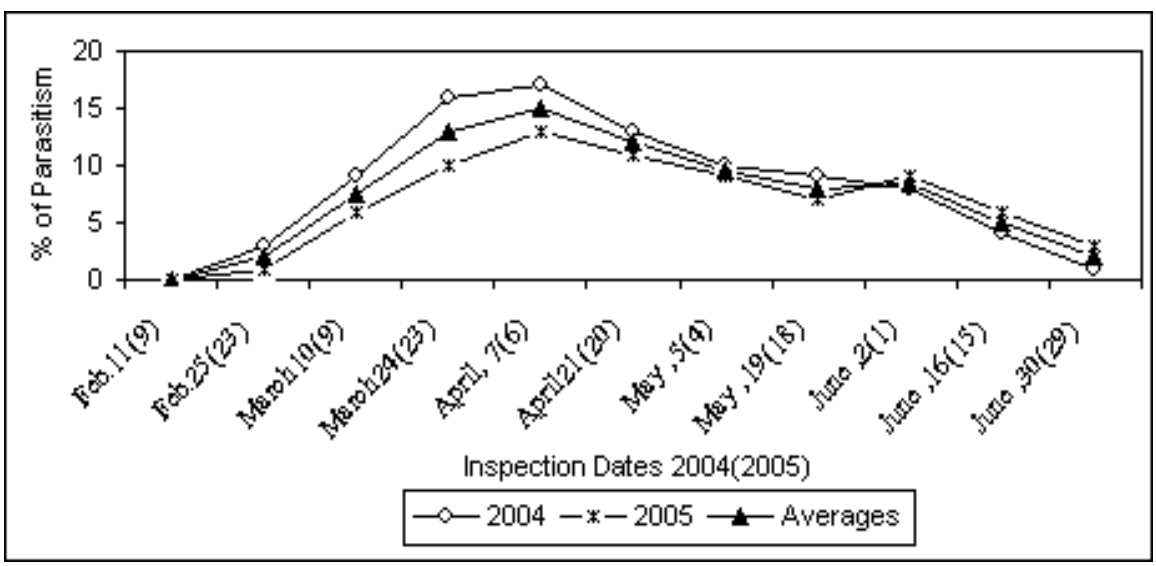

Fig. 2. Occurrence of $\%$ of parasitism on peach twig borer Anarsia lineatella during two successive seasons of 2004 and 2005 


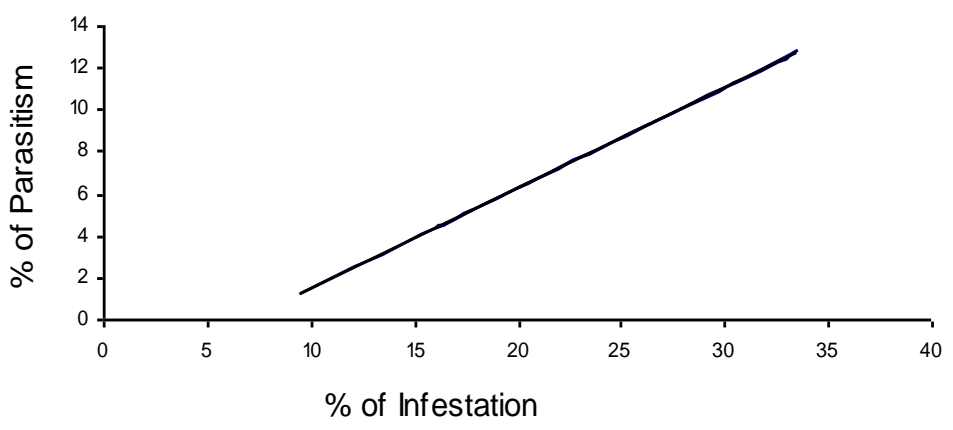

Fig. 3. Regression line between $\%$ of infestation by peach twig borer and $\%$ of associated parasites

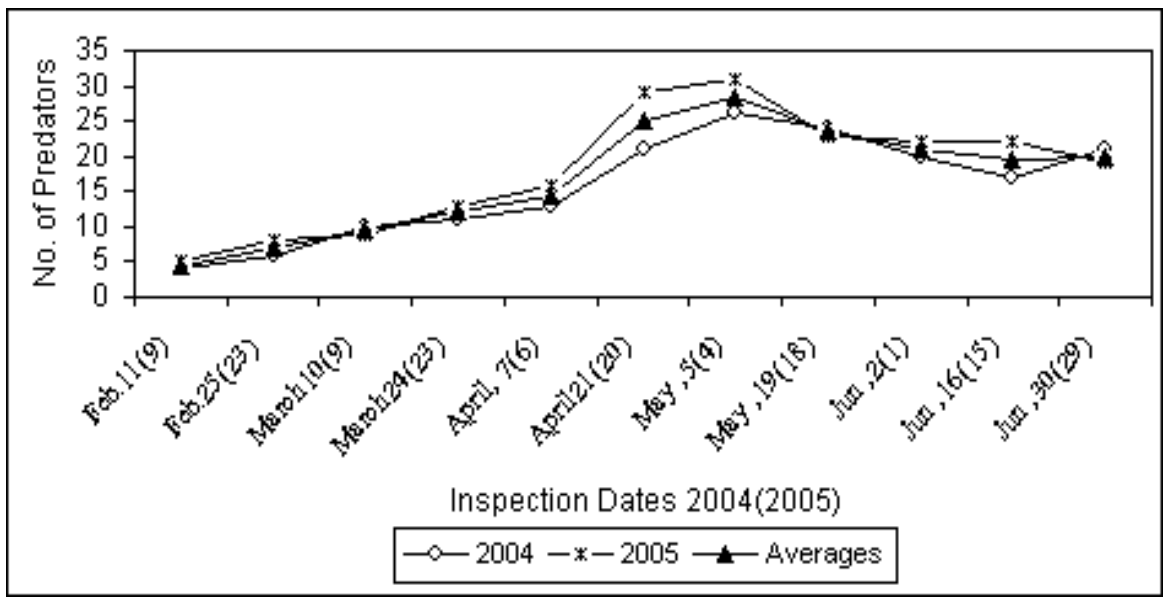

Fig. 4. Occurrence of number of predators on peach twig borer Anarsia lineatella during two successive seasons of 2004 and 2005. 
of twigs infested with larvae increased, mainly in April. These finding are in agreement with those of Weakley et al 1990; Saafan, et al 1994 and Hrdy, et al 1994.

The larvae prefer pre-mature fruits than twigs .So the infestation by larvae increased in fruits than twigs in May, Table (1). These results are coincide with those of Saafan, 1992 and Barnett and Hendricks, 1992.

\section{Bio Agents}

\section{A. Parasites}

Now a day, chemical pesticides are not favourable to use for controlling the pests especially in fruit trees. So, parasites may be playing an important role for control, or at least decrease, number of such pest, especially during the active periods of larvae. The present investigation revealed that larvae of peach twig borer Anarsia lineatella were found to be parasitized by the following three species of hymenopterous parasitoids:

i. Apanteles ruficrus Haliday (Fam. Braconidae)

iii. Diplazon laetatorus Fab. (Fam. Ichneumonidae)

iii. Microgaster tiro Reinhard (Fam. Braconidae)

The rate of parasitism coincides with that of infestation by pests. Percentages of parasitism are increased according to increasing the rate of infestation which 10.25 and $13.5 \%$ in March and April, respectively and then decreased, gradually, till reach 8.25 and $5.16 \%$ in May and June respectively, Table (2) and Fig. (2). According to the time coordination, the correlation coefficient showed a positive significance between the number of parasites and the rate of infestation $(\mathrm{r}=+$
$0.799 * *$ and $b=+0.476)$, Fig. (3). These results are agree with those of (Dimova, 1987 and Cravedi et al 1995) who emphasized to use the bioagents, especially parasites, in the Integrated Pest Management (IPM) programs.

\section{B. Predators}

Four predatory species were found associated with the peach twig borer Anarsia lineatella on peach trees:

i. Coccinella undecimpunctata L (Coleoptera: Coccinellidae)

ii. Rodalia cardinalis Mulsant (Coleoptera: Coccinellidae)

iii. Scymnus syriacus Marseul (Coleoptera: Coccinellidae)

iv. Syrphus sp. (Diptera: Syrphidae).

The predators seems to be less active than that of parasites, since the average number of predators recorded 5.75, 10.75, 19.75, 26 and 20 during February, March, April, May and June respectively, Table (2) and Fig. (4). These numbers seems to be few than that expected to be found. It may be due to the behaviour of such pest. Positive correlation between the number of predators and the rate of infestation $(\mathrm{r}=$ $+0.423(\mathrm{p}=0.422))$ was detected. On the other hand the relationship between parasites and predator appear no significant correlation between each others $(r=$ 0.371).

\section{REFRENCES}

Barnett, W.W. and L.C. Hendricks (1992). Comparison of pheromone trap catches to adult emergence and oviposition of peach twig borer, Anarsia lineatella Zeller. Acta-phytopathologic Entomologic Hungarica. 27(1): 85-88. Cravedi, P.; F. Guarino and A. Tocci (1995). Photosanitary situation of peach 
tree in Calabria (South Italy). Bulletin OILB SROP. 18(2): 51-54.

Dimova, M. (1987). The parasitic entomofauna of Anarsia lineatella Zell. (Gelechiidae) and Grapholitha molesta Busck (Torricidae ; Lepidopttera ) and its impotance in reducing the density of these pest. Pochvoznanie, Agrokhimiya Rastitelne-Zashchita. 22(6): 87-92.

Hathaway, D.; G. Tamaki; H. Moffitt and A. Burditt (1985). Impact of removal of males with sex-pheromone - baited traps on suppression of the peach -twig borer, Anarsia lineatella (Zeller). Canadin Entomolgist. 117(5): 643-645.

Hrdy, I.; J. Marek; F. Kraml; J. Kuldova and L. Barabas (1994). Distribution of the fruit tree pests Cydia molesta ,Cydia funebrana and Anarsia lineatella Zell. (Lepidoptera, Tortricidae, Gelichiidae). In former Czechoslovakia as recorded by pheromone traps. Acta Societatis Zoologica Bohemicae. 58(1): 53-60.

Ivanova, L.; R. Gulcan and U. Aksoy (1995). Studies on the biology and the ecological peculiarities of Anarsia lineatella Zell. in the region of Silistra. Acta Horticulturae. 38(4): 601-605.

Kehat, M; L. Anshelevich; E. Dunkelblum and S. Greenberg (1994). Sex pheromone traps for monitoring the peach twig borer, Anarsia lineatella Zell. Effect of pheromone components, pheromone dose, field aging of dispenser, and type of trap on male captures. Phtoparasitica. 22(4): 291-298.

Kocourek. F.; J. Berankova and I. Hrdy (1996). Flight patterns of the peach twig borer, Anarsia lineatella Zell. in Central Europe as observed using pheromone traps. Anzeiger fur Schadlingskunde Pflanzenschutz, Umweltschutz. 69(4): 84-87.
Molinari, F. and P. Cravedi (1991). The defence of peach by the confusion method. Informatore Agrario. 41(5): 26-28. Molnar, J. (1991). Monitoring of peach twig borer (Anarsia lineatella Zell., Glechiidae) by means of pheromone trap. Polnohospodartvo. 37(11): 988-999. (CAB Abstracts 931178768).

Pari, P.; G. Spada; M. Garaffoni; P. Guardigni; R. Canestrale; R. Minguzzi; M. Ravaioli and G. Carli (1990). Use of the mating disruption technique to control Cydia molesta Busk and Anarsia lineatella Z. in peach orchards in Emilia Romagnqa. Informatore Fitopatologico. 40(10): 35-42.

Saafan, M.H. (1992). Ecological studies on the peach twig borer, Anarsia lineatella (Zeller) on apricot trees, Egypt. $J$. Agric. Res., 70(3): 753-761.

Saafan, M.H.; S.M. Foda and M.A. Korashy (1994). Ecological studies on the peach twig borer, Anarsia lineatella (Zeller) at North Sinai Governorae, Egypt.J.Appl. Sci., 9(7): 595- 601.

Weakley, C.V.; P.A. Kirsch and F.G. Zalom (1990). Within orchard and within tree distribution of peach twig borer (Lepidoptera: Gelechiidae) damage to peaches. Journal of Econmic Entomlogy. 83(2): 505-510.

Yonugman, R.R. and M.M. Barnes (1985). The longevity of attractiveness of the commercially available pheromone septa of the peach twig borer (Lepidotera: Gelichiidae). Journal of Econmic Entomlogy. 78(1): 110-112.

Zalom, F.G.; W.W. Barnet; R.E. Rice and C.V. Weakley (1992). Factors associated with flight patterns of the peach twig borer (Lepidotera: Gelichiidae) observed using pheromone traps. Journal of Econmic Entomlogy 85(5): 1904-1909. 
بحلة اتحاد الجحامعات العربية للدراسات والبحوث الزراعية ، جامعة عين شمس ، القاهرة 14(2) ، 813-821 ، 2006 نشاط حشرة ثاقبة براعم الخوخ Anarsia lineatella والاعداء الحيوية المصاحبة لها على اشجار الخوخ

[52]

\section{سلوى سيد محمد عبد الصمد1}

1 - قسم بحوث المكافحة الحيوية- معهد بحوث وقاية النبات- مركز البحوث الزراعية - جيزة - مصر

Apanteles ruficrus: غثائيه الاجنحه هى Diplazon laetatorus و (Fam. Braconidae) Microgaster tiro g(Fam. Ichneumonidae) حيث تصل أعلى نسبة (Fam. Braconidae)

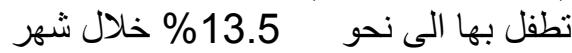
ابريل. وقد اظهر حساب مدى الارتباط بين

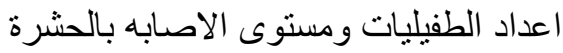
ان الطفيليات تبدو اكثر فاعلية في مقاومة الاصنية

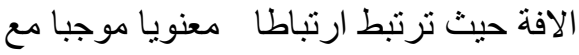

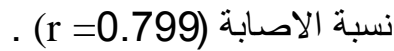

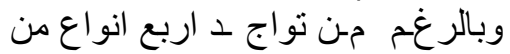
المفترسات هى:

Rodalia, Coccinella undeximpunctata Scymnus syriacus, cardinalis Syrphus sp. (Coleoptera: Coccinellidae) الا ان ارتباطهـا بنسبة (Diptera: Syrphidae) الاصابة كان ضعيفا نظر القلة أعدادها.
درس النشاط الموسم يى لحشرة ثاقبة

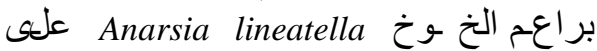

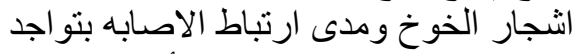

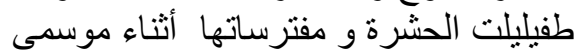

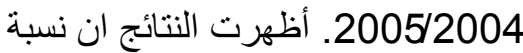

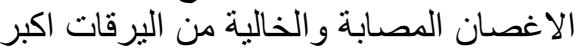

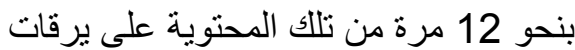

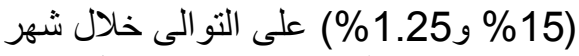

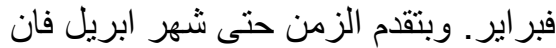
الوضع ينعكس حيث سجلت نسبة الاصنية

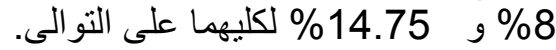

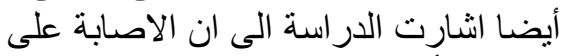

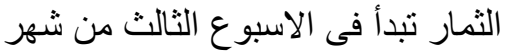

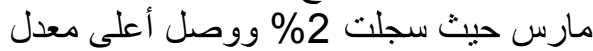

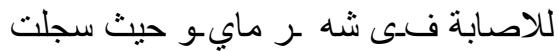
\%16.75

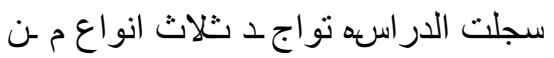

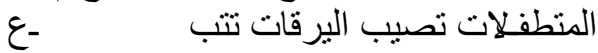

تحكيم: أ.د رشدى رزق الله

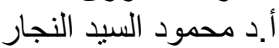

